\title{
Specific Inhibition of elF-5A and Collagen Hydroxylation by a Single Agent Antiproliferative and Fibrosuppressive Effects on Smooth Muscle Cells from Human Coronary Arteries
}

Timothy A. McCaffrey, ${ }^{*}$ Kenneth B. Pomerantz, * Timothy A. Sanborn, ${ }^{5}$ Artur M. Spokojny, ${ }^{5}$ Baoheng Du, ${ }^{*}$ Myung-Hee Park, " John E. Folk, ' Arja Lamberg, ** Kari I. Kivirikko, ** Domenick J. Falcone, ${ }^{\star}$ Semil B. Mehta, * and Hartmut M. Hanauske-Abel"

${ }^{*}$ Department of Medicine, Division of Hematology/Oncology, ${ }^{\ddagger}$ Department of Pathology, Cell Biology and Anatomy, ${ }^{8}$ Cardiac Catheterization Laboratory, and "Department of Pediatrics, Cornell University Medical College, The New York Hospital, New York 10021; 'National Institutes of Health, National Institute of Dental Research, Laboratory of Cellular Development and Oncology, Bethesda, Maryland 20892; and **Department of Medical Biochemistry, Oulu University, Oulu, Finland

\begin{abstract}
Restenosis occurs in $35 \%$ of patients within months after balloon angioplasty, due to a fibroproliferative response to vascular injury. These studies describe a combined fibrosuppressive/antiproliferative strategy on smooth muscle cells cultured from human primary atherosclerotic and restenotic coronary arteries and from normal rat aortas. LMimosine suppressed the posttranslational hydroxylation of the precursors for collagen and for eukaryotic initiation factor-5A (eIF-5A) by directly inhibiting the specific protein hydroxylases involved, prolyl 4-hydroxylase (E.C. 1.14.11.2) and deoxyhypusyl hydroxylase (E.C. 1.14.99.29), respectively. Inhibition of deoxyhypusyl hydroxylation correlated with a dose-dependent inhibition of DNA synthesis. Inhibition of prolyl hydroxylation caused a dose-dependent reduction in the secretion of hydroxyproline-containing protein and decreased the formation of procollagen types I and III. The antifibroproliferative action could not be attributed to nonspecific or toxic effects of mimosine, appeared to be selective for the hydroxylation step in the biosynthesis of the procollagens and of eIF-5A, and was reversible upon removal of the compound. The strategy of targeting these two protein hydroxylases has important implications for the pathophysiology of restenosis and for the development of agents to control fibroproliferative diseases. ( $J$. Clin. Invest. 1995. 95:446-455.) Key words: vascular smooth muscle • cell division $\cdot$ collagen $\cdot$ hydroxylases $\cdot$ mimosine
\end{abstract}

\section{Introduction}

Cell proliferation and matrix production are important elements of any tissue's response to injury. Both processes are essential in physiological wound repair, but, in excess, they contribute

Address correspondence either to Timothy A. McCaffrey, Ph.D., Cornell University Medical College, Department of Medicine, Division of Hematology/Oncology, Rm. C-608, 1300 York Avenue, New York, NY 10021, Phone: 212-746-2089; FAX: 212-746-8866 or to Hartmut M. Hanauske-Abel, M.D., Ph.D., Cornell University Medical College, Department of Pediatrics, Division of Endocrinology, Rm. N-236, 525 East 68th Street, New York, NY 10021, Phone: 212-746-1894; FAX: 212746-0300. 1994.

Received for publication 1 April 1994 and in revised form 11 July

The Journal of Clinical Investigation, Inc.

Volume 95, February 1995, 446-455 to pathological conditions that can compromise organ function. One of the most destructive clinical manifestations of excessive wound healing occurs at focal sites in the vasculature. Atherosclerotic lesions, with their associated mineralization and lipid accumulation, lead to ischemic, rheological, and prothrombotic complications in coronary, carotid, and peripheral arteries (1). Although angioplasty can achieve initial reperfusion in $95 \%$ of atherosclerotic occlusions, progressive fibroproliferative reocclusion occurs within 6 mo postoperatively in at least $35 \%$ of the more than 300,000 patients in the United States alone (2). Despite promising results in animal models, restenosis in humans has been resistant to a variety of medical interventions (for review see reference 2 ).

The predominant proliferative component of the restenotic lesion is a large dendritic cell expressing the contractile $\alpha$-actin isoform (3), a marker for both smooth muscle cells (SMC) ${ }^{1}$ and myofibroblasts (4). SMC derived from restenotic lesions proliferate more rapidly than cells from primary atherosclerotic lesions $(5,6)$. In experimental models of arterial injury, SMC show a proliferative peak 4-7 d after injury followed by elevated proliferation for weeks after injury $(7,8)$. SMC at the injury site rapidly increase gene expression of profibrotic cytokines such as transforming growth factor- $\beta 1$ (TGF- $\beta 1$ ), followed by markedly enhanced expression of collagen type I and III component $\alpha$ chains (9). SMC derived from restenotic lesions produce two- to threefold higher levels of collagen and proteoglycans than SMC derived from umbilical arteries (10). Collagens are known to act as a scaffold for proteoglycans and glycoproteins $(11,12)$ and, thus, form a depository for TGF$\beta 1$ (13-15), PDGF (16), and the fibroblast growth factors (17). These matrix-bound mediators could provide an ongoing signal for proliferation, matrix production, and augmented growth factor expression (18). In this way, the de novo synthesis of collagens could create an intralesional nidus of profibrotic growth factors which sustain the fibroproliferative response.

We noted that both cell proliferation and extracellular matrix formation depend on the hydroxylation of specific proteins, the eukaryotic initiation factor-5A (eIF-5A) and the collagens, respectively. In eIF-5A, this unique hydroxylated amino acid residue is hypusine [ $N^{\epsilon}$-(4-amino-2 $(R)$-hydroxybutyl)lysine]. The synthesis of functional eIF-5A involves two distinct posttranslational modifications: $(a)$ the $\mathrm{NAD}^{+}$-dependent transfer of a spermidine-derived 4-aminobutyl moiety onto the $\epsilon$-amino

1. Abbreviations used in this paper: eIF-5A, eukaryotic initiation factor$5 \mathrm{~A}$; $\mathrm{IC}_{50}$, half-maximal inhibitory concentration; $\mathrm{LDH}$, lactate dehydrogenase; PAI-1, plasminogen activator inhibitor-1; PIIINP, $\mathrm{NH}_{2}$-terminal propeptide of type III procollagen; SMC, smooth muscle cells. 


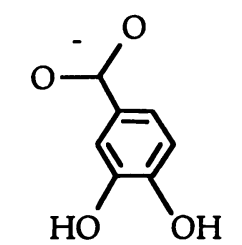

\section{3,4-Dihydroxy- benzoic acid}

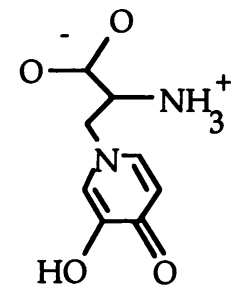

Mimosine

Figure 1. Chemical structure of 3,4-dihydroxybenzoic acid, L-mimosine, and kojic acid.

group of a single sequence-defined lysine residue, generating deoxyhypusine (19); and (b) the stereospecific hydroxylation of its carbon 9 by the metalloenzyme deoxyhypusyl hydroxylase (E.C. 1.14.99.29), generating hypusine (20). Hypusine has been identified only in eIF-5A $(21,22)$. Inhibition of deoxyhypusyl hydroxylase correlates with reversible arrest of cell proliferation, causing the accumulation of cells in the late G1 phase of the cell cycle, apparently by interfering with the onset of DNA replication $(21,23)$.

In collagens, the crucial hydroxylated residues are trans 4hydroxyprolines, formed posttranslationally by prolyl 4-hydroxylase (E.C. 1.14.11.2). This enzyme, an $\alpha_{2} \beta_{2}$-tetrameric, divalent iron-containing dioxygenase, stoichiometrically uses 2-oxoglutarate and molecular oxygen for the hydroxylation of a sequence-defined proline residue. The mechanism of prolyl 4hydroxylase proposed by Hanauske-Abel and Günzler (24) has been used successfully to guide the design of prolyl 4-hydroxylase inhibitors $(25,26)$. Suppression of prolyl hydroxylation prevents the formation of the collagenous triple helix which is required for the secretion of at least the interstitial procollagens. In this way, inhibition of prolyl 4-hydroxylase selectively reduces formation of the extracellular matrix (25).

The active sites of deoxyhypusyl hydroxylase and prolyl 4hydroxylase have been probed with reporter molecules (27, 28 ). Both protein hydroxylases recognize -Gly-x-y-Gly- motifs in their respective substrates and both.of their active sites contain (a) a tightly bound metal ion accessible to low molecular weight ligands; and $(b)$ an ionic side chain for salt-bridging ligands. Certain catecholpeptides which mimic the -Gly-x-yGly - motif and inhibit purified prolyl 4-hydroxylase also suppress deoxyhypusyl hydroxylase in vitro (27). Nonpeptide compounds like 3,4-dihydroxybenzoic acid (3,4-DHBA) also inhibit both protein hydroxylases $(27,29)$. The catecholpeptides and 3,4-DHBA are, however, not stable under biological conditions due to the redox reactivity of their aromatic dihydroxybenzene moiety (30). Thus, L-mimosine, a naturally occurring catechol analogue with a biologically stable, nonaromatic 3-hydroxypyridin-4 one ring, was selected as a pilot compound (Fig. 1).

These studies provide the first evidence that mimosine, but not its ring isomer kojic acid, acts as an inhibitor for both protein hydroxylases in cultured vascular cells. The suppression of cell proliferation and collagen secretion is demonstrated in rat aortic SMC and in cells from primary stenosing and restenotic human coronary lesions. Local delivery of this type of protein hydroxylase inhibitor during recanalization procedures might favorably influence the fibroproliferative sequelae of vascular interventions.

\section{Methods}

Reagents. L-Mimosine (3-( $N$-(3-hydroxypyridin-4-one))-2[S]-aminopropionic acid) and kojic acid (5-hydroxy-2-hydroxymethyl- $\gamma$-pyrone) were purchased from Aldrich Chemical Co. (Milwaukee, WI). The radiochemicals [terminal methylenes- ${ }^{3} \mathrm{H}(N)$ ]-spermidine $(15 \mathrm{Ci} /$ $\mathrm{mmol}), \mathrm{L}-\left[5-{ }^{3} \mathrm{H}\right]$-proline $(28 \mathrm{Ci} / \mathrm{mmol}), 2-\mathrm{oxo}\left[1-{ }^{14} \mathrm{C}\right]$ glutarate $(40$ $\mathrm{mCi} / \mathrm{mmol})$, and [methyl ${ }^{3} \mathrm{H}$ ] thymidine $(20 \mathrm{Ci} / \mathrm{mmol})$ were purchased from New England Nuclear (Wilmington, DE). (Pro-Pro-Gly) $10 \times 9$ $\mathrm{H}_{2} \mathrm{O}$ was obtained from the Protein Research Foundation (Minoh, Osaka, Japan). Catalase was obtained from Sigma Chemical Co. (St. Louis, MO).

Human tissue sampling. Coronary vessel wall biopsies were obtained by directional atherectomy (Simpson AtheroCath; DVI, Inc., Redwood City, CA) as a part of routine procedures from patients undergoing interventional treatment for coronary stenosis in the Coronary Catheterization Unit of The New York Hospital/Cornell Medical Center, New York. All specimens used in this study were waste tissue collected in accordance with a protocol approved by the Institutional Review Board.

Cell culture. Human coronary SMC were obtained by the following procedure. Atherectomy specimens were finely diced and placed onto collagen-coated (Vitrogen; Collagen Corp., Palo Alto, CA) flasks in medium 199 containing $20 \%$ fetal bovine serum (FBS) and gentamycin sulfate $(50 \mu \mathrm{g} / \mathrm{ml}$, all from Gibco Laboratories, Grand Island, NY). Cells extending from the explants onto the flasks surface were subpassaged with trypsin/EDTA (Gibco Laboratories) and used within the first five passages. Cell cultures were obtained from primary atherosclerotic and from restenotic lesions as specified for each experiment. Rat aortic SMC were isolated similarly from explants of the aortic media of male Sprague-Dawley rats and cultured in medium 199/10\% FBS/ gentamycin sulfate.

Histology. A portion of each atherectomy specimen was fixed in $10 \%$ buffered formalin for routine histology. Both formalin-fixed tissue and cells plated onto 8-chamber glass slides were immunostained using a mouse monoclonal antibody specific for the contractile smooth muscle $\alpha$-actin (clone No. 1A4; Sigma Chemical Co.) which was detected with FITC- or peroxidase-labeled anti-mouse immunoglobulins (Sigma Chemical Co.). Nonimmune mouse serum was used as a control and showed no staining. Sections were photographed with a Nikon Labophot 2 fluorescence microscope.

Cell proliferation. Inhibition of DNA synthesis was examined by semiautomated methods. SMC were plated at $1 \times 10^{4}$ cells/well of $96-$ well microtiter plates at least $24 \mathrm{~h}$ before the assay. Agents were introduced into normal serum-containing growth media for $20 \mathrm{~h}$ before the cells were pulsed with $\left[{ }^{3} \mathrm{H}\right]$ thymidine $(1 \mu \mathrm{Ci} / \mathrm{ml})$ for $4 \mathrm{~h}$. Cells were collected with trypsin and a cell harvester (Wallac, Gaithersburg, MD), and the DNA-incorporated label was determined by scintillation counting (Betaplate; Wallac) $(n=6$ per point).

Toxicity. The effect of mimosine and kojic acid on cellular integrity and metabolic function was determined by standard techniques. The release of lactate dehydrogenase $(\mathrm{LDH})$ was determined in serum-free SMC supernatants using an autoanalyzer (Synchron CX7; Beckman Instruments, Inc., Fullerton, CA). Membrane integrity was verified by trypan blue exclusion.

Deoxyhypusyl hydroxylation in cells. To determine the conversion of deoxyhypusine to hypusine in cells, nonconfluent cultures of human or rat SMC $\left(1 \times 10^{6}\right.$ cells per $25-\mathrm{cm}^{2}$ flask $)$ were preincubated for 60 $\mathrm{min}$ at the specified inhibitor concentrations. Cells were then labeled with $\left[{ }^{3} \mathrm{H}\right]$ spermidine $(5 \mu \mathrm{Ci} / \mathrm{ml})$ for $24 \mathrm{~h}$, harvested with trypsin/ EDTA, and precipitated three times with $10 \%$ TCA containing $1 \mathrm{mM}$ each of putrescine, spermidine, and spermine. The final precipitate was hydrolyzed $\left(6 \mathrm{~N} \mathrm{HCl}, 110^{\circ} \mathrm{C}, 16 \mathrm{~h}\right)$, lyophilized, resuspended in water, and analyzed on an amino acid analyzer as described (31).

Prolyl hydroxylation in cells. Human or rat SMC (3-5 $\times 10^{5}$ cells/ 
35-mm well) were labeled in the presence or absence of inhibitor, with $\left[{ }^{3} \mathrm{H}\right]$ proline $(4 \mu \mathrm{Ci} / \mathrm{ml})$ for $24 \mathrm{~h}$ in proline- and serum-free DME containing $50 \mu \mathrm{g} / \mathrm{ml}$ sodium ascorbate and $20 \mu \mathrm{g} / \mathrm{ml} \beta$-aminopropionitrile, as described previously (32). The supernatants were precipitated in $10 \% \mathrm{TCA}$, hydrolyzed $\left(6 \mathrm{~N} \mathrm{HCl}, 110^{\circ} \mathrm{C}, 16 \mathrm{~h}\right)$, and lyophilized. The hydrolysate was derivatized with phenylisothiocyanate and analyzed for $\left[{ }^{3} \mathrm{H}\right]$ proline and $\left[{ }^{3} \mathrm{H}\right]$ hydroxyproline on a reverse-phase $\mathrm{C} 18$ column $(33,34)$, using an automated HPLC system (Hewlett-Packard Co., Wilmington, DE) with an in-line scintillation counter (Inus Systems, Inc., Tampa, FL). All concentrations were tested in replicates of three wells.

Assays of purified human prolyl 4-hydroxylase. The native $\alpha_{2} \beta_{2-}$ tetrameric enzyme was purified to homogeneity by poly ( $L$-proline) affinity chromatography and DEAE chromatography from the supernatant of Spodoptera frugiperda insect cells cotransfected with recombinant baculovirus transfer vectors for both the human $\alpha$ - and $\beta$-subunits (35). Enzyme activity was determined by trapping of ${ }^{14} \mathrm{CO}_{2}$ released from 2 oxo $\left[1-{ }^{14} \mathrm{C}\right]$ glutarate as described $(28)$. Briefly, all incubations were run for $60 \mathrm{~min}$ at $37^{\circ} \mathrm{C}$ in a final volume of $1.0 \mathrm{ml}$ per test sample, containing $0.1 \mu \mathrm{g}$ enzyme, $0.1 \mathrm{mg}$ heat-denatured (Pro-Pro-Gly) ${ }_{10} \times 9 \mathrm{H}_{2} \mathrm{O}$ as hydroxylatable substrate, $0.1 \mathrm{mM} 2-0 x 0\left[1-{ }^{14} \mathrm{C}\right]$ glutarate adjusted to $60,000 \mathrm{dpm}$ by mixing with the unlabeled 2-oxoglutarate as cosubstrate, and cofactors ( $1.6 \mathrm{mM}$ ascorbate, $0.05 \mathrm{mM}$ ferrous sulfate, $0.08 \mathrm{mM}$ dithiothreitol, $2 \mathrm{mg}$ BSA, 3,750 U catalase).

Determination of type I and type III procollagen secretion. Human SMC (3-5 $\times 10^{5}$ cells $/ 35-\mathrm{mm}$ well), grown to confluence and incubated in serum-free DME containing $50 \mu \mathrm{g} / \mathrm{ml}$ sodium ascorbate and $20 \mu \mathrm{g} / \mathrm{ml} \beta$-aminopropionitrile, were exposed for $24 \mathrm{~h}$ to increasing concentrations of test compounds. After centrifugation, to clear any cellular debris, these supernatants were used to determine the levels of type I and III procollagens.

For determination of type I procollagen, supernatants were precipitated with $10 \%$ TCA and electrophoresed under nonreducing conditions on a 4-20\% SDS-PAGE gel. The gel was transferred to nitrocellulose with a semidry blotter (Bio-Rad Laboratories, Hercules, CA). The membrane was blocked with $1 \%$ goat serum $/ 1 \%$ BSA and then incubated with a 1:200 dilution of a rabbit polyclonal antiserum (LF41) against a 21-amino acid synthetic peptide homologous to the $\mathrm{COOH}$-terminal sequence of the C-propeptide of the component $\alpha 1$ chain of human type I procollagen. Because in each type I procollagen molecule two of these globular domains are disulfide-linked to the $\mathrm{COOH}$-terminal globular domain of one component $\alpha 2$ chain, this antibody can be used under nonreducing conditions to detect trimeric, native C-propeptide [C3] proteolytically released during procollagen-collagen conversion (36). The antiserum was raised by Dr. L. Fisher (National Institutes of Health, Bethesda, MD) and kindly provided by Dr. D. J. Prockop (Jefferson University, Philadelphia, PA). Nonimmune rabbit serum was used as a control and did not detect bands in the $\mathrm{C} 3$ region. Immunoblots were scanned with a UMAX UC630 flatbed scanner and quantified densitometrically using NIH Image software for the Macintosh.

For determination of type III procollagen, supernatants were analyzed by RIA (PIIINP RIA-gnost ${ }^{\mathrm{TM}}$; Behringwerke-Hoechst AG, Frankfurt, Germany) for antigenic material derived from the $\mathrm{NH}_{2}$-terminal propeptide of type III procollagen (PIIINP). This assay uses a monoclonal mouse antibody (MAK 226) that preferentially recognizes intact human PIIINP and has low affinity for PIIINP degradation products such as the Col-1 fragment (RIA-gnost P III P technical manual, p. 12). The antigen concentration in each sample was interpolated from a PIIINP standard curve. Sample wells were assayed in duplicate and a minimum of three wells per concentration were averaged.

Plasminogen activator inhibitor-1 (PAI-1) assay. Supernatants of human atherectomy-derived SMC incubated with mimosine or kojic acid under serum-free conditions (to avoid plasma-derived inhibitors) were tested for their ability to inhibit a standard amount of urokinasetype plasminogen activator in the presence of plasminogen and the fluorometric peptide plasmin substrate d-Val-Leu-Lys-aminomethylcoumarin (Enzyme Systems, Livermore, CA). Inhibition of plasmin genera- tion was compared with a standard curve of human PAI-1 (American Diagnostica Inc., Greenwich, CT) to yield PAI-1 activity.

\section{Results}

Subculture of human vascular cells. Morphologically, coronary artery wall biopsies were notable for their relative acellularity, and the abundant accumulation of collagen, as visualized by the prominent blue counterstain using Masson's trichrome technique (37) (Fig. 2, upper left). Both primary atherosclerotic and restenotic lesions showed strong immunostaining for the contractile smooth muscle $\alpha$-actin isoform in the majority of the large, noninflammatory cells, consistent with the presence of SMC $(3,38)$ or related myofibroblasts (4) (Fig. 2, upper right).

Atherectomy specimens from 195 patients undergoing treatment for coronary stenosis or restenosis were examined for their ability to yield primary cultures. In $21 \%$ of the specimens, cells initially spread onto the culture flask surface, but only $4 \%$ produced sustained cultures of SMC. Cells proliferating from these explants can show delayed outgrowth (average latency is $24 \mathrm{~d}$ ), long doubling times, and abrupt growth inhibition upon minimal cell-cell contact. These cells exhibited long dendritic projections (Fig. 2, lower left). A high percentage (30-40\%) of cells spontaneously showed strong reactivity toward the anti$\alpha$-actin antibody (Fig. 2, lower right), and essentially all cells became $\alpha$-actin-positive upon serum withdrawal and treatment with TGF- $\beta 1$ ( $<1 \mathrm{ng} / \mathrm{ml})$, a characteristic of both SMC (39) and myofibroblasts $(4,40)$.

Effect of mimosine and kojic acid on cellular deoxyhypusyl hydroxylase activity. The inhibition of deoxyhypusyl hydroxylase has been shown to correlate with proliferative arrest at the G1-S boundary (23). When the enzyme was studied in vitro, mimosine caused almost complete inhibition at $50 \mu \mathrm{M}$, whereas even $300 \mu \mathrm{M}$ of kojic acid was not inhibitory (23). Deoxyhypusyl hydroxylase activity in SMC also was not suppressed by kojic acid (data not shown), but mimosine had a marked inhibitory effect. In atherectomy-derived human SMC and in normal rat aortic SMC, mimosine caused a dose-dependent decrease of the enzyme's hydroxylated product, hypusine, and a concomitant increase in the unhydroxylated intermediate, deoxyhypusine (Fig. 3). Metabolic labeling of the SMC with $\left[{ }^{3} \mathrm{H}\right]-$ spermidine for $24 \mathrm{~h}$, followed by acid hydrolysis and amino acid analysis, revealed that, under control conditions, essentially all of the $\left[{ }^{3} \mathrm{H}\right]$ spermidine-derived radioactivity was found in a single peak eluting in the position of purified hypusine. At $\mathbf{4 0 0}$ $\mu \mathrm{M}$ mimosine, however, most of the $\left[{ }^{3} \mathrm{H}\right]$ spermidine-derived, protein-bound label in the human cells was shifted into the position of deoxyhypusine. Significantly, despite this marked suppression of cellular deoxyhypusyl hydroxylase activity $(80 \%)$, mimosine had only a marginal effect $(15 \%)$ on the overall incorporation of $\left[{ }^{3} \mathrm{H}\right]$ spermidine-derived label into precursor eIF-5A (Fig. 3, inset). Dose-response analysis in rat SMC confirmed that maximal inhibition of cellular deoxyhypusyl hydroxylase activity is achieved at $400 \mu \mathrm{M}$ mimosine, with an apparent half-maximal inhibitory concentration $\left(\mathrm{IC}_{50}\right)$ of 160 $\mu \mathrm{M}$ (Fig. 3). Total [ $\left.{ }^{3} \mathrm{H}\right]$ spermidine incorporation was unaffected in the 100-200 $\mu \mathrm{M}$ range and was reduced at $400 \mu \mathrm{M}$ by just $11 \%$. These findings suggest that significant disruption by mimosine of the metabolic steps before hydroxylation of the eIF-5A precursor did not occur. Apparently, the biosynthetic flow through the hypusination pathway, with its key elements 

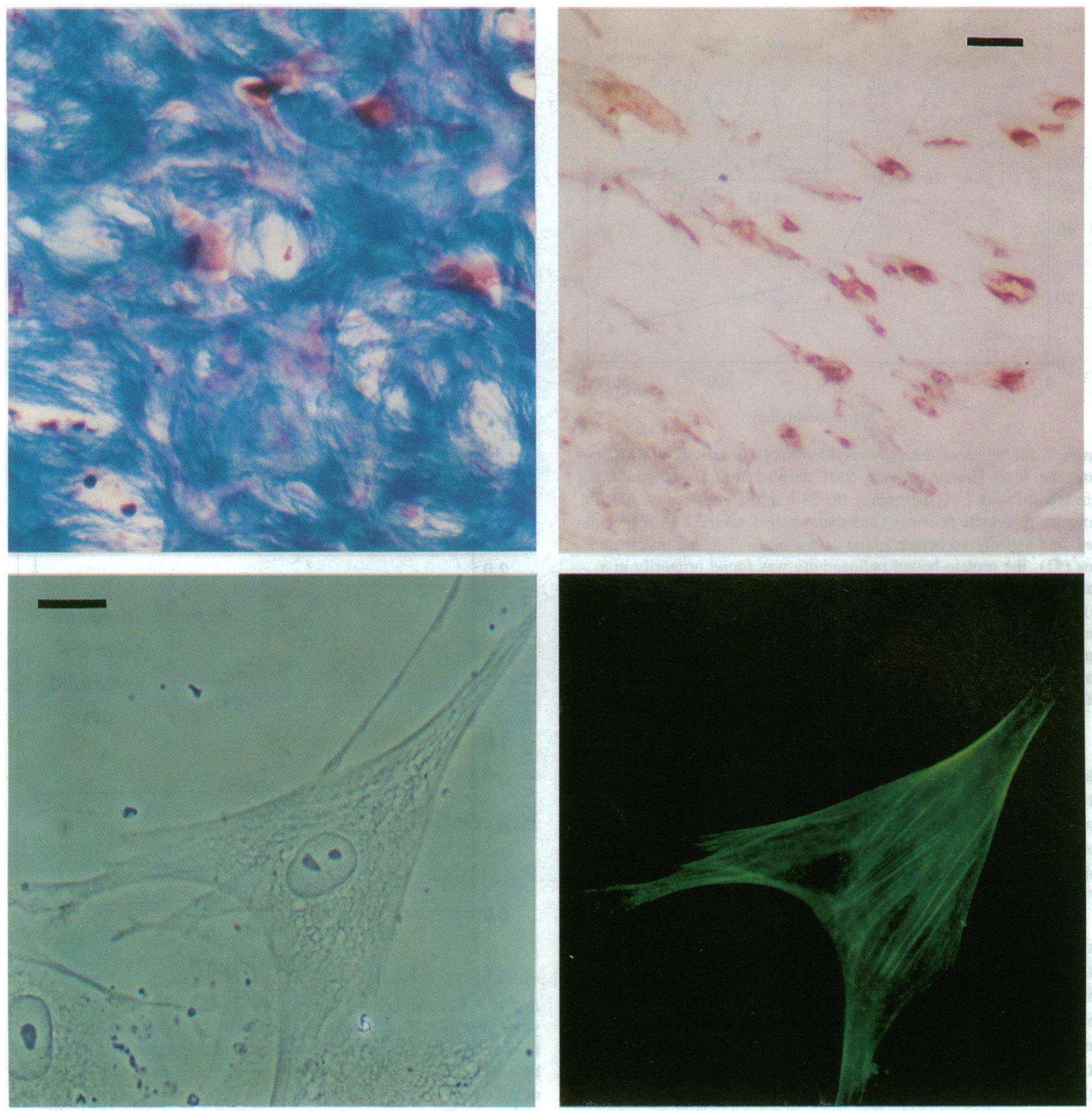

Figure 2. Histology, immunocytochemistry, and cell culture of human coronary atherosclerotic lesions recovered by directional atherectomy. Upper left, Masson's trichrome stain of a restenotic lesion recovered from a 60 -yr-old male 4.5 mo after balloon angioplasty showing the presence of a few large dendritic cells (red) within an extensive collagenous matrix (blue). Upper right, Immunocytochemical identification (immunoperoxidase) of contractile $\alpha$-actin-reactive cells showing the presence of smooth muscle-like cells (reddish brown) within the atherosclerotic lesion (Bar $=20 \mu \mathrm{m}$ for both upper panels). Lower left, Phase-contrast micrograph of cells cultured from explants of the lesion shown in the upper right (Bar $=20 \mu \mathrm{m}$ for both lower panels). Lower right, Immunocytochemical identification (FITC) of $\alpha$-actin contractile fibers within one of the cells shown in the previous panel.

of polyamine transport, protein precursor formation, and butylamine transfer, continues unaffected at concentrations of mimosine that completely suppress its final step, deoxyhypusyl hydroxylation.

The effect of mimosine and kojic acid on vascular cell proliferation. Mimosine was a potent inhibitor of DNA synthesis in SMC derived from primary atherosclerotic lesions, with an apparent $\mathrm{IC}_{50}$ of $\sim 90 \mu \mathrm{M}$ (Fig. 4, top). Two separate SMC cultures derived from restenotic lesions were also inhibited by mimosine by an average of $90 \%$ at $500 \mu \mathrm{M}$, with an average $\mathrm{IC}_{50}$ of $100 \mu \mathrm{M}$ (not shown). In contrast, kojic acid was not an effective antiproliferative agent in the dose range tested. Likewise, DNA replication in primary cultures of rat aortic SMC was inhibited by mimosine with an apparent $\mathrm{IC}_{50}$ of 100 $\mu \mathrm{M}$ (Fig. 4 , bottom). In cells from both species, inhibition of proliferation was essentially complete at $400 \mu \mathrm{M}$ mimosine, 


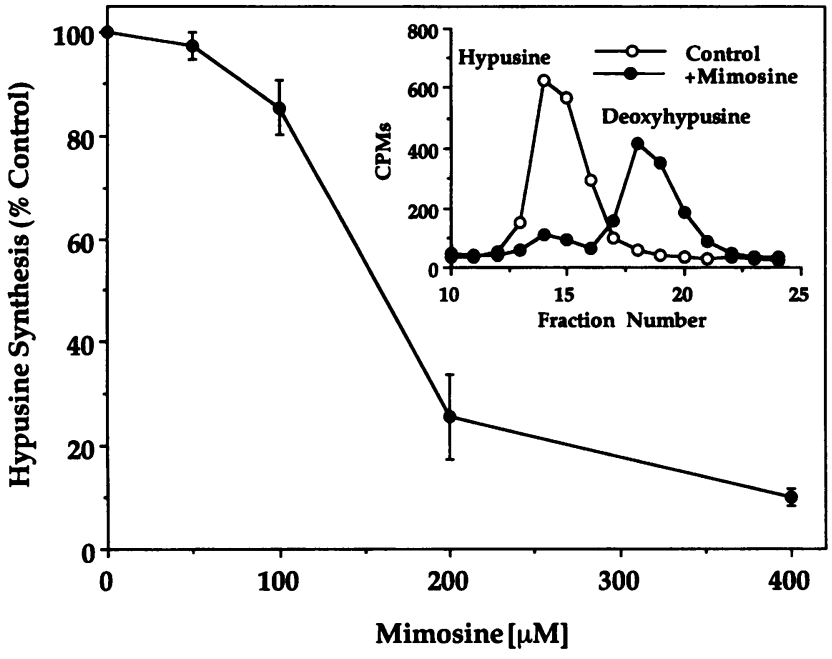

Figure 3. Inhibition of deoxyhypusyl hydroxylase activity in SMC by mimosine. Inset, Human coronary SMC derived from a restenotic lesion were labeled with $\left[{ }^{3} \mathrm{H}\right]$ spermidine for $24 \mathrm{~h}$ in the presence of $400 \mu \mathrm{M}$ mimosine or vehicle (Control) and then washed, scraped, TCA precipitated, and hydrolyzed before amino acid analysis. Under control conditions $(O)$, the protein-bound radioactivity was found primarily in a peak corresponding to authentic hypusine. In the presence of mimosine $(\bullet)$, the label shifted to the unhydroxylated form, deoxyhypusine. Main panel, Dose-response analysis in rat aortic SMC under identical conditions indicating a calculated $\mathrm{IC}_{50}$ of $150 \mu \mathrm{M}$ mimosine required to inhibit deoxyhypusine conversion to hypusine (points are percentage of control $\left[{ }^{3} \mathrm{H}\right]$ hypusine synthesis expressed as mean $\pm \mathrm{SEM}, n=3$ ).

whereas kojic acid had little effect up to $1 \mathrm{mM}$. Mimosine's antiproliferative effect extended with similar dose-response characteristics to human umbilical vein endothelial cells, human monocyte-like cells (THP-1, ATCC; American Type Culture Collection, Bethesda, MD), and a rat aortic SMC line (RA10, ATCC).

The antiproliferative effect was fully reversible upon withdrawal of mimosine when corrected for cell number (Fig. 4, bottom). After the initial 24-h incubation, DNA synthesis was inhibited by mimosine, but not by kojic acid. Upon drug removal and an additional 24-h recovery period, there was a marked rebound DNA synthesis in the mimosine-arrested, but not in the kojic acid-treated cells. This finding is consistent with synchronous release of a large cohort of SMC from a mimosine-sensitive arrest point just before initiation of DNA replication, an effect previously demonstrated by flow cytometry in other cell types (23). Cell cycle analysis using acridine orange-stained rat SMC confirmed that mimosine induced a reversible accumulation of cells at the G1-S boundary (not shown).

Effect of mimosine and kojic acid on purified human prolyl 4-hydroxylase. The structural similarities between mimosine and 3,4-dihydroxybenzoic acid (Fig. 1), a known prolyl-4-hydroxylase inhibitor, suggested that mimosine and kojic acid might be effective inhibitors. Thus, the interaction of mimosine and kojic acid with the purified human enzyme was investigated. As the active site metal ion is reversibly lost under nonturnover conditions, the enzyme becomes metal-depleted during purification and needs to be restored in vitro by the addition of ferrous ions (41). Mimosine interfered with the reconstitution of the active enzyme, showing an apparent $\mathrm{IC}_{50}$ of $120 \mu \mathrm{M}$, whereas
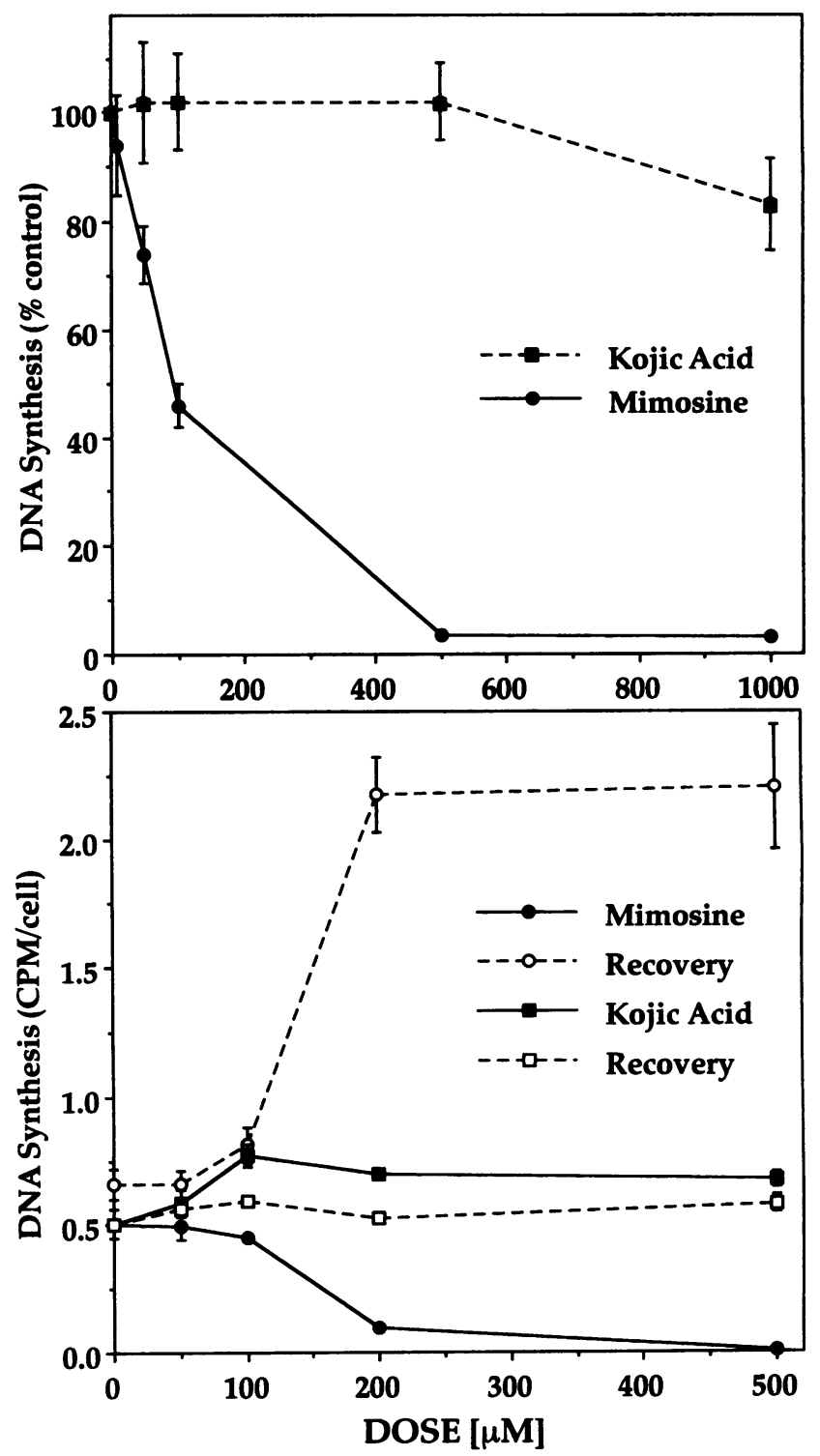

Figure 4. Reversible inhibition of SMC proliferation by protein hydroxylase inhibitors. Top, Serum-stimulated DNA synthesis in SMC derived from a primary human coronary atherosclerotic lesion was determined by a 4-h pulse of $\left[{ }^{3} \mathrm{H}\right]$ thymidine $20 \mathrm{~h}$ after treatment with mimosine or kojic acid at the specified doses. Data are expressed as percent control $\left[{ }^{3} \mathrm{H}\right]$ thymidine incorporation (mean \pm SEM, $n=6$ per point). Bottom, Rat aortic SMC were incubated under similar conditions with mimosine or kojic acid for $20 \mathrm{~h}$ before a 4-h pulse of $\left[{ }^{3} \mathrm{H}\right]$ thymidine (closed symbols). Identically treated cells were then washed and returned to fresh culture media without inhibitors for an additional $20 \mathrm{~h}$ before labeling with $\left[{ }^{3} \mathrm{H}\right]$ thymidine (open symbols). Parallel wells were trypsinized and counted in a ZBI particle counter (Coulter Corp., Hialeah, FL) after $24 \mathrm{~h}$ with inhibitor and $24 \mathrm{~h}$ after inhibitor withdrawal (Recovery). After recovery, control wells contained $31,593 \pm 76.9$ SMC compared with $22,280 \pm 583.9$ SMC in mimosine-containing wells (control vs $400 \mu \mathrm{M}$ mimosine, $P<0.001$ ). Data are expressed as a percentage of control $\left[{ }^{3} \mathrm{H}\right]$ thymidine incorporation per cell (mean $\pm \mathrm{SEM}, n=3$ ) to compensate for changes in cell number after inhibitor exposure.

kojic acid was relatively ineffective, with an apparent $\mathrm{IC}_{50}$ of $>300 \mu \mathrm{M}$ (Fig. 5). Such a differential effect was also observed for inhibition of deoxyhypusyl hydroxylase in vitro (23), al- 


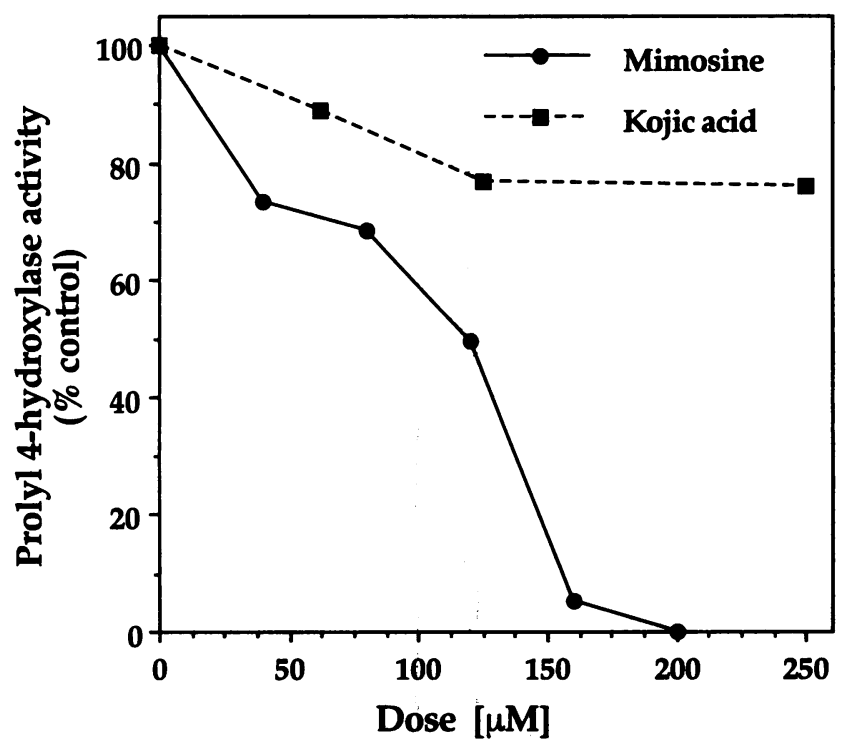

Figure 5. Inhibition of purified prolyl 4-hydroxylase activity by mimosine. Enzyme activity was determined by trapping of ${ }^{14} \mathrm{CO}_{2}$ released from a reaction mixture of the human recombinant enzyme, (Pro-Pro-Gly) ${ }_{10}$ as hydroxylatable substrate, $2-\mathrm{oxo}\left[1-{ }^{14} \mathrm{C}\right]$ glutarate, ascorbate, and ferrous sulfate. Data are expressed as a percentage of activity in the absence of inhibitor.

though both compounds share the physicochemical ability to interact with metal ions in solution $(42,43)$. Thus, only mimosine, but not kojic acid, was inhibitory, apparently by interfering with the apoenzyme to enzyme conversion.

Effect of mimosine and kojic acid on cellular prolyl 4hydroxylase activity. To determine whether these compounds were capable of suppressing prolyl-4-hydroxylase activity in vascular SMC, cells were treated with mimosine for $24 \mathrm{~h}$ under proline-free, serum-free conditions before 24-h pulse-labeling with $\left[{ }^{3} \mathrm{H}\right]$ proline. Mimosine inhibited prolyl hydroxylase activity in human and rat SMC in a dose-dependent manner and at $400-500 \mu \mathrm{M}$ reduced hydroxyprolyl generation by $80-90 \%$. At that concentration, $\left[{ }^{3} \mathrm{H}\right]$ proline incorporation, used as a general index for total protein biosynthesis, declined by $<20 \%$ in human SMC and was increased by $20 \%$ in rat SMC (Fig. 6). These results indicate that mimosine quite specifically inhibits prolyl hydroxylation, with minimal, if any, consequence for the overall synthesis of cellular proteins. In culture, such a preferential effect has been observed before only with agents that directly interact with prolyl 4-hydroxylase, whereas a metal chelator, like 2,2'-dipyridyl, diminishes hydroxyprolyl generation and total protein biosynthesis to the same degree (32). In contrast, kojic acid caused only a $30 \%$ reduction in hydroxyproline formation at $500 \mu \mathrm{M}$ and, thus, was less effective than mimosine. The suppression of cellular prolyl hydroxylase activity by mimosine was rapidly reversible upon removal of the inhibitor. Rat SMC treated with mimosine $(500 \mu \mathrm{M})$ for 24 $\mathrm{h}$ showed hydroxyproline/proline ratios reduced to $<60 \%$ of control levels $(P<0.01)$, which significantly increased to $90 \%$ of control levels $24 \mathrm{~h}$ after drug withdrawal $(P<0.05)$.

Effect of mimosine on the secretion of type $I$ and III procollagens in human vascular SMC. Type I and III procollagens are the most prominent collagenous proteins synthesized by vascular SMC in their synthetic state, which predom-

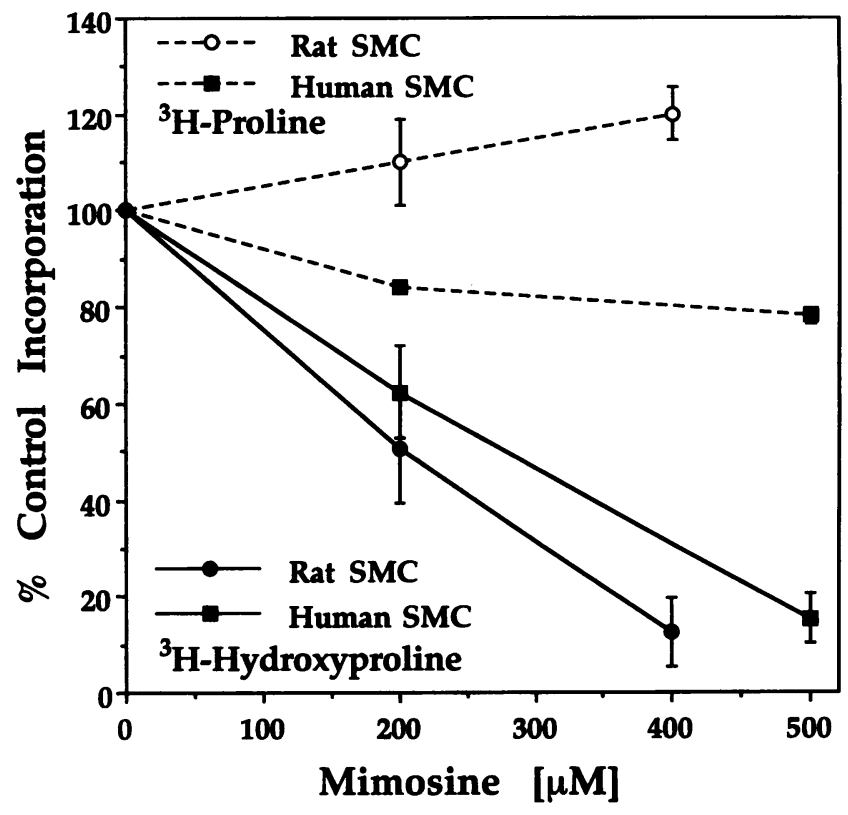

Figure 6. Inhibition of prolyl hydroxylation in human coronary and rat aortic SMC by mimosine. SMC derived from a human coronary restenotic lesion (shown in Fig. 2, upper left) or rat aortic SMC were pretreated with mimosine at the specified levels for $30 \mathrm{~min}$ before labeling with $\left[{ }^{3} \mathrm{H}\right]$ proline for $24 \mathrm{~h}$. The supernatants were TCA precipitated and hydrolyzed, and $\left[{ }^{3} \mathrm{H}\right]$ proline and $\left[{ }^{3} \mathrm{H}\right]$ hydroxyproline levels were determined by HPLC. Data are mean \pm SEM, $n=3$ per point.

inates after passaging in culture and is thought to be representative of cells in vascular lesions (44). Type III procollagen expression increases as a reaction to injury of the rat aorta in vivo (9). In humans, the serum levels of PIIINP are known to indicate fibrotic changes in the coronary arteries (45). PIIINP is cleaved extracellularly by a specific $\mathrm{N}$-proteinase before fibril formation, and, thus, is a stoichiometric marker for matrix deposition of type III collagen. Consistent with its ability to suppress prolyl hydroxylation, mimosine reduced PIIINP secretion to $\sim 50 \%$ of control levels (Fig. 7). In contrast, the production of PAI-1, a noncollagenous protein, was not affected even at the highest inhibitor concentrations. Thus, it is unlikely that mimosine causes a nonspecific reduction of protein export in general, but, rather, this compound appears to decrease the secretion of proteins which, like the interstitial procollagens, display a triple helical and therefore hydroxyproline-dependent domain. Such a discriminating effect was observed previously with specific prolyl 4-hydroxylase inhibitors like the pyridine dicarboxylates (32).

In vivo, type I collagen is also expressed by SMC in response to vascular injury (9). In the current study, the secretion of procollagen type I was examined by Western blot analysis using a polyclonal antibody directed against the globular, trimeric C-propeptide C3 which is proteolytically cleaved by a specific C-proteinase from the hydroxyproline-containing triple helix in a 1:1 ratio upon secretion (36). The formation in the supernatant of the 72-kD C3 antigen was markedly decreased by mimosine over a 24-h period (Fig. 8). Densitometric analysis of triplicate immunoblots indicated a reduction of $\mathrm{C} 3$ to $\sim 50 \%$ at the highest concentration of mimosine.

The immunological techniques used for measuring C3 and PIIINP exhibited less marked decreases in response to mimosine 


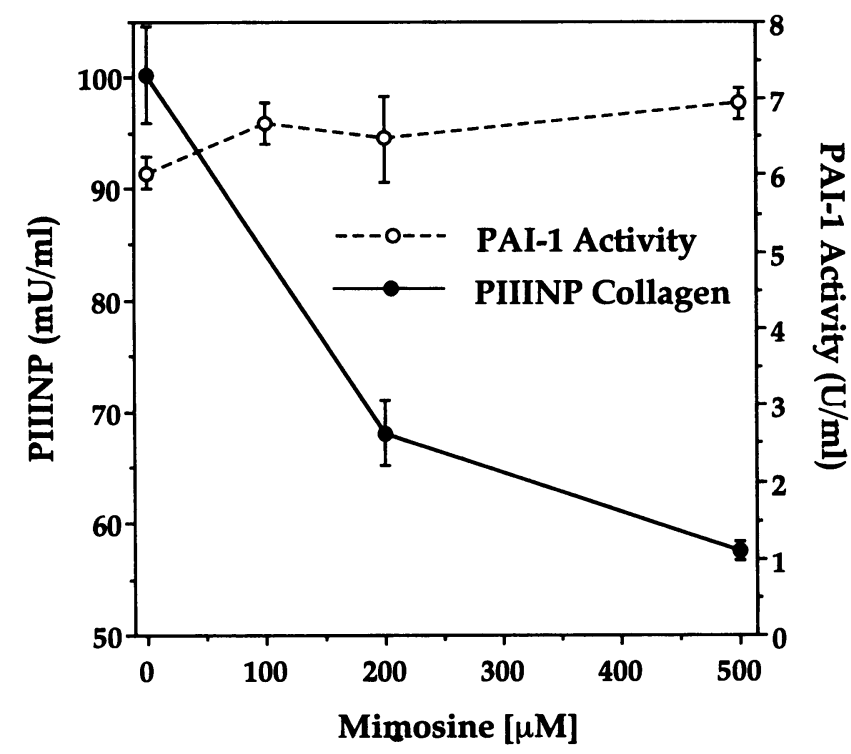

Figure 7. Secretion of PIIINP and PAI-1 activity from human coronary SMC. SMC derived from a restenotic coronary plaque were treated under serum-free conditions for $24 \mathrm{~h}$ with the specified doses of mimosine followed by PIIINP RIA (left axis, closed symbols). Data are expressed in milliUnits per milliliter of supernatant (mean \pm SEM, $n=3$ ). PAI-1 was assayed by fluorometric assay for the inhibition of plasmin generated from urokinase and plasminogen (right axis, open symbols). Levels were interpolated from a standard curve of human PAI-1 expressed in Units per milliliter (mean \pm SEM, $n=3$ ).

when compared with the nearly complete inhibition of prolyl hydroxylation. The antigenic measures probably underestimate true inhibition for two reasons. First, the antibodies may react with underhydroxylated collagenous peptides that are slowly released from the cells in the presence of inhibitors (25). Sec-

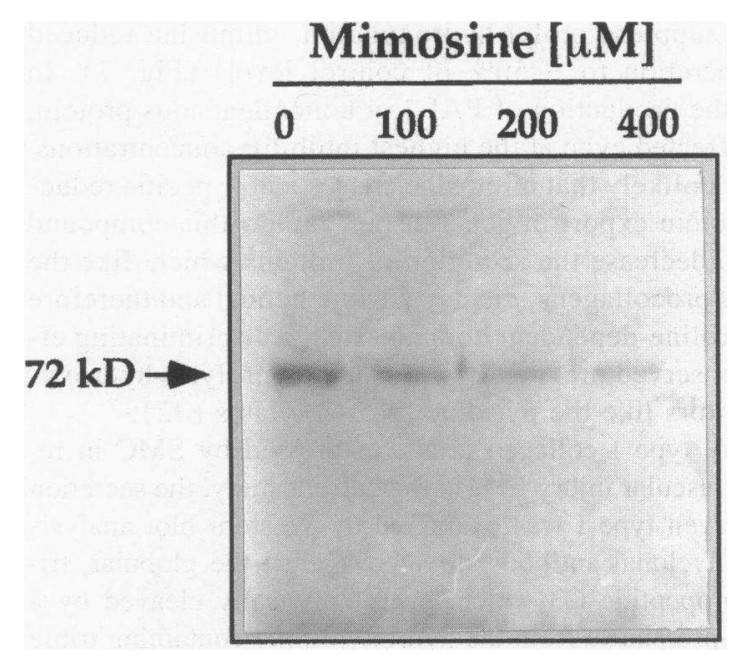

Figure 8. Secretion of procollagen type I C-propeptide (C3) by coronary artery SMC. Serum-free supernatants from human coronary restenotic SMC cultures were collected during a 24-h incubation with mimosine. Supernatants were precipitated with $10 \%$ TCA, separated by $4-20 \%$ SDS-PAGE under nonreducing conditions, transferred to nitrocellulose, and probed with a polyclonal anti-C3 antibody, detected by an immunoperoxidase-labeled anti-mouse antibody from rabbit.
Table I. The Effect of L-Mimosine and Kojic Acid on LDH Release and Trypan Blue Exclusion in Vascular Smooth Muscle Cells

\begin{tabular}{crcccc}
\hline Agent & Dose & LDH release & SEM & Trypan blue & SEM \\
\hline & $\mu M$ & $m U / m l$ & & \% positive & \\
Mimosine & 0 & 57.00 & 1.00 & 0.16 & 0.011 \\
& 500 & 54.50 & 0.50 & 0.40 & 0.025 \\
Kojic acid & 0 & ND & - & 0.16 & 0.011 \\
& 500 & ND & - & 0.13 & 0.019
\end{tabular}

LDH levels were determined by autoanalyzer in the supernatants of rat aortic SMC incubated with mimosine for $24 \mathrm{~h}$ under conditions identical to those used for DNA synthesis studies $(n=2)$. Hypotonic injury to control cells run in parallel showed a marked elevation of LDH release (114 mU/ml). Trypan blue dye exclusion was performed on rat SMC under similar conditions. The number of positively stained cells, indicating loss of membrane integrity, was expressed as a percentage of cells in each well as determined by a ZBI particle counter (Coulter Corp.) $(n=3)$.

ond, the antibodies cannot discriminate propeptides formed rapidly during secretion from propeptides slowly released from the matrix.

Toxicity of mimosine and kojic acid. In the time frame tested, no sign of toxicity of mimosine on SMC was observed. In addition to the reversibility of the inhibitory effects on proliferation and collagen hydroxylation, the cells remained viable and biosynthetically active as demonstrated by $(a)$ the number of trypan blue-excluding cells (Table I); $(b)$ the absence of detectable leakage of cytoplasmic LDH (Table I); and (c) the continued synthetic capacities, as reflected by the metabolic labeling of new protein with $\left[{ }^{3} \mathrm{H}\right]$ proline (Fig. 6) and of precursor eIF-5A with $\left[{ }^{3} \mathrm{H}\right]$ spermidine (Fig. 3 ), and by the unaffected secretion of PAI-1 activity (Fig. 7).

\section{Discussion}

The vascular response to injury, in the form of cell migration, cell proliferation, and extracellular matrix accumulation, is driven by numerous growth factors and cytokines (1). Because of this inherent mediator redundancy, intentional interruption of the response to an individual mediator may be insufficient to alter the overall tissue reaction. The present strategy targets the pivotal posttranslational hydroxylation of proteins required in the common pathway of both cell proliferation and collagen synthesis, irrespective of which growth factors and cytokines drive these responses. The antifibroproliferative effect of a protein hydroxylase inhibitor, like mimosine, is unconstrained by the biological complexity of the mediator network underlying fibroproliferative diseases.

The intentional interference with specific posttranslational modifications is a widely accepted principle of medical therapeutics and a routine event in clinical practice. The coumarinlike oral anticoagulants are inhibitors of protein carboxylation occurring in Factors II, VII, IX, and X. Likewise, the antithyroid drugs are inhibitors of protein iodination occurring in thyroglobulin. The proposed mechanism for inhibitors of protein hydroxylation, which, like mimosine, affect the production of physiologically structured interstitial procollagens and of eIF-5A, is 


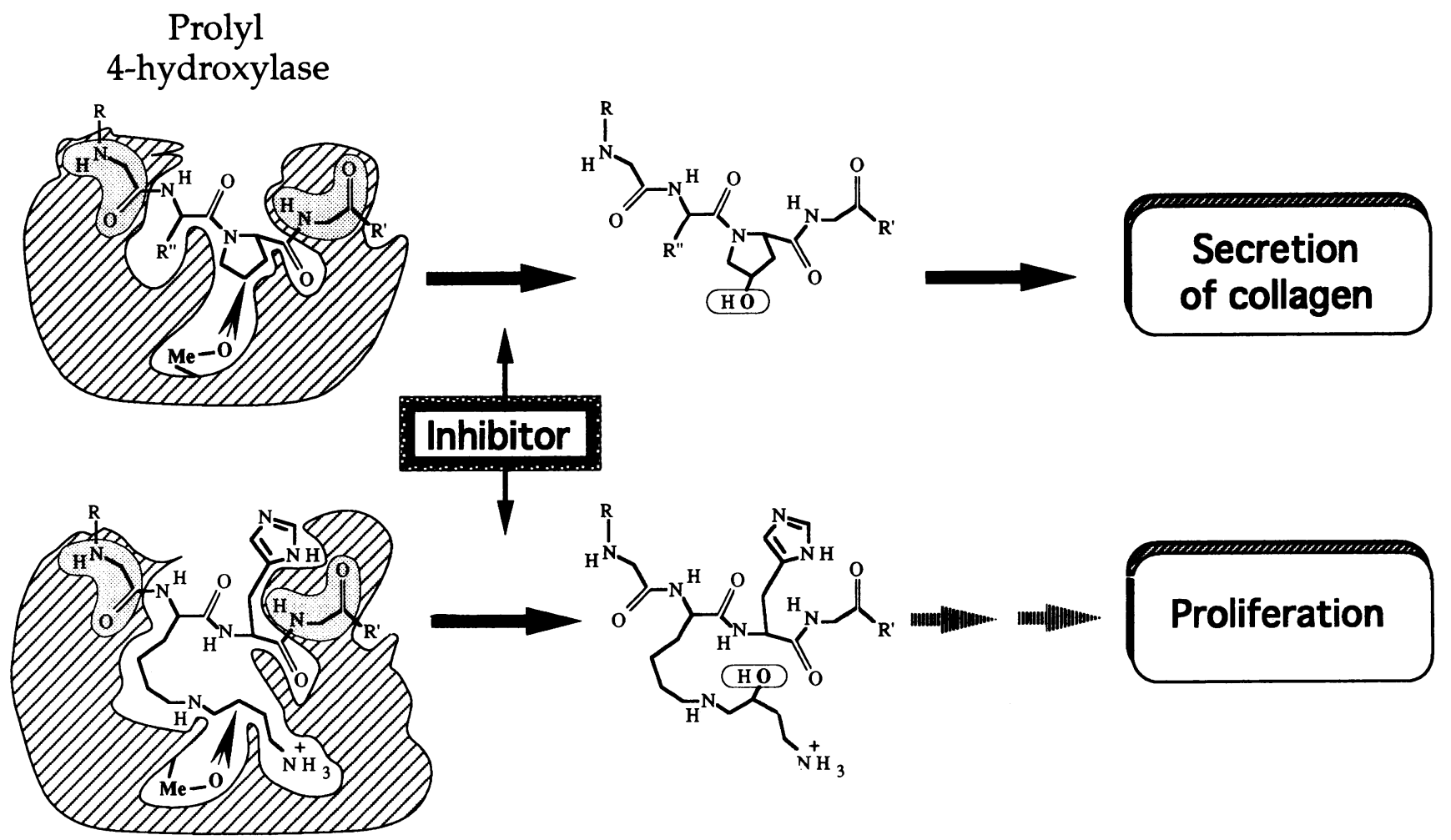

$$
\begin{gathered}
\text { Deoxyhypusyl } \\
\text { hydroxylase }
\end{gathered}
$$

Figure 9. Proposal for the antifibroproliferative effect of a protein hydroxylase inhibitor such as mimosine. The diagram emphasizes the similarity in active site organization between prolyl 4-hydroxylase and deoxyhypusyl hydroxylase with regard to their respective peptide substrate, which in each case displays a -Gly-x-y-Gly motif (glycine residues highlighted in gray), and its relation to the active site metal ( $M e$ ) which is thought to generate and orient a reactive oxygen atom species $(O)$ for stereospecific attack on the prolyl $\mathrm{C} 4$ and the deoxyhypusyl $\mathrm{C} 9$ atoms, in this way mediating hydroxylation (arrows) $(24,25,27)$. Apparently, mimosine is able to access the tightly bound metal ion $(M e)$ and to block its role in catalysis. Inhibition of prolyl 4-hydroxylase directly suppresses the hydroxyproline-dependent formation and secretion of triple helical collagens (25); inhibition of deoxyhypusyl hydroxylase compromises cell proliferation, by a mechanism not yet completely understood in molecular detail (23).

summarized in Fig. 9. The function suppressed in each biosynthetic pathway is the posttranslational formation of the hydroxylated, peptide-bound amino acid residues trans 4-hydroxyproline and hypusine, which are required for the biological activity of these proteins. In the absence of physiologically structured collagens and eIF-5A, connective tissue formation and cell proliferation both come to a halt independently and both resume rapidly upon removal of the inhibitor. The reversibility of these effects implies that, in vivo, the inhibitor will need to be present until the mitogenic and profibrotic stimuli have subsided.

The present results indicate that a single inhibitor of protein hydroxylation is able to suppress both collagen secretion and cell proliferation in cultured vascular cells of the human coronary arteries and the rat aorta. Mimosine directly inhibits prolyl 4-hydroxylase (Fig. 5) and deoxyhypusyl hydroxylase (23), which in cells blocks the secretion of de novo synthesized collagens (25) and inhibits cell proliferation (23) (Figs. 4 and 6). Inhibition of prolyl 4-hydroxylation leads to intracisternal misfolding of only the collagenous proteins, resulting in a dosedependent reduction of their secretion $(32,46)$. Apparently, mimosine selectively inhibits hydroxylase activity, which re- sides in the $\alpha$ subunits of prolyl 4-hydroxylase (47), but does not compromise the role of its $\beta$ subunits in the intracellular retention of misfolded procollagens (48).

The simultaneous suppression of both protein hydroxylases by a single agent implies that, in addition to the similarities in their peptide binding sites, the active sites of prolyl 4-hydroxylase and deoxyhypusyl hydroxylase are structured alike. Indeed, the three-dimensional models proposed for the architecture of each enzyme's active site $(24,25,27)$ show common structural elements which outline the structure-activity relation for the dual action of mimosine.

In both enzymes, the protein-bound metal atom at the active site, proposed to mediate the hydroxylation by transfer of an oxygen atom (Fig. 9), provides coordination sites for a bidentate ligand. The active sites are thought to also display a polar amino acid side chain able to form a stabilizing salt bridge with an appropriately charged ligand, requiring a negative charge in case of prolyl 4-hydroxylase and a positive charge in case of deoxyhypusyl hydroxylase $(24,25,27)$. We propose that these structural prerequisites for interaction with either enzyme are met by the amino acid moiety of mimosine. Its ionic interaction 
positions the 3-hydroxy-4-keto moiety to chelate the active site metal of each protein hydroxylase. This hypothesis accounts for the fact that mimosine-like molecules require a carboxyl moiety to inhibit procollagen formation $(29,49)$, whereas they require an amino group to inhibit proliferation (50). These distinctions may be useful for the further development of compounds that selectively target only one protein hydroxylase. Indeed, the potent prolyl 4-hydroxylase antagonists pyridine 2,4-dicarboxylate and pyridine 2,5-dicarboxylate (28) lack the ability to inhibit deoxyhypusyl hydroxylase (20) and they do not affect cell proliferation or cell cycle transit (McCaffrey, T. A., and H. M. Hanauske-Abel, unpublished observation).

The prerequisite for interaction with both the charged side chains and the metal ion appears to be quite stringent for prolyl 4-hydroxylase and for deoxyhypusyl hydroxylase, as evidenced by the findings obtained with kojic acid. This agent, which cannot bind to the charged side chain at the active site of either enzyme, but whose ring is bioisosteric to the one in mimosine (Fig. 1) and like mimosine interacts with metal, was not inhibitory for deoxyhypusyl hydroxylase (23) and only weakly inhibitory for prolyl 4-hydroxylase (Fig. 5). Therefore, the ability to bind metal is, by itself, not sufficient to effectively access the active site of either prolyl 4-hydroxylase or deoxyhypusyl hydroxylase and inhibit enzyme activity. Generalized metal chelation by an agent like desferrioxamine can, however, reduce vascular SMC proliferation in vitro and in vivo (51).

After oral administration in animals, plasma levels of mimosine could be maintained in the range of concentrations that were biologically active in the present studies $(100-300 \mu \mathrm{M})$ (52). However, because both protein hydroxylases have important functions in normal tissue, ideally their use would be restricted to the site of the fibroproliferative response. Fortunately, drugs, or bioactivatable prodrugs, could be applied locally either by a perfusion catheter (53) or by resorbable vascular stents acting as a depot for the slow release of agent into the local environment (54). Intramural application of these agents would also place the inhibitor beneath the intimal surface and would thus minimize the antiproliferative effect on reendothelialization, which occurs both by migration and proliferation (55). Thus, the antifibroproliferative action of protein hydroxylase inhibitors could be targeted to specific vascular regions to interfere with the establishment of an intralesional collagenous nidus of factors that sustain the fibroproliferative response. Protein hydroxylase inhibitors, like mimosine, will be useful tools for determining the impact of cell proliferation and collagen synthesis in vascular restenosis and other fibroproliferative disorders.

\section{Acknowledgments}

The authors wish to thank Hoechst AG for providing technical support and access to the radioimmunoassays for determination of human procollagen type III $\mathrm{NH}_{2}$-terminal propeptide. The authors are indebted to Dr. Ken Emancipator for generous use of the Synchron CX7 autoanalyzer. H. M. Hanauske-Abel wishes to thank Dr. Maria New for special assistance.

H. M. Hanauske-Abel was supported in part by the Evariste Galois Fund and the Council for Tobacco Research. The contributions of K. I. Kivirikko and A. Lamberg were made possible by grants from the Medical Research Council of the Academy of Finland. T. A. McCaffrey is a recipient of an NIH FIRST Award (HL-42606). T. A. McCaffrey, K. Pomerantz, and D. Falcone are members of an NIH Program Project in Atherosclerosis (HL-46403). Parts of this work were conducted in association with an NIH SCOR in Thrombosis (HL-18828).

\section{References}

1. Ross, R. 1993. The pathogenesis of atherosclerosis: a perspective for the 1990s. Nature (Lond.). 362:801-809.

2. Herrman, J.-P. R., W. R. M. Hermans, J. Vos, and P. W. Serruys. 1993 Pharmacological approaches to the prevention of restenosis following angioplasty: the search for the Holy Grail? (Part I). Drugs. 46:18-52.

3. Dartsch, P. C., I. Bauridel, I. Schinko, H. D. Weiss, B. Hfling, and E. Betz. 1989. Cell constitution and characteristics of human atherosclerotic plaques selectively removed by percutaneous atherectomy. Atherosclerosis. 80:149-157.

4. Desmoulière, A., A. Geinoz, F. Gabbiani, and G. Gabbiani. 1993. Transforming growth factor- $\beta 1$ induces $\alpha$-smooth muscle actin expression in granulation tissue myofibroblasts and in quiescent and growing cultured fibroblasts. $J$. Cell Biol. 122:103-111.

5. Dartsch, P. C., R. Voisard, G. Bauridel, B. Hfling, and E. Betz. 1990 Growth characteristics and cytoskeletal organization of cultured smooth muscle cells from human primary stenosing and restenosing lesions. Arteriosclerosis. 10:62-75.

6. Pickering, J. G., L. Weir, K. Rosenfield, J. Stetz, J. Jekanowski, and J. M. Isner. 1992. Smooth muscle cell outgrowth from human atherosclerotic plaque: implications for the assessment of lesion biology. J. Am. Coll. Cardiol. 20:14301439.

7. Stemerman, M. B., R. Weinstein, J. W. Rowe, T. Maciag, R. Fuhro, and R. Gardner. 1982. Vascular smooth muscle cell growth kinetics in vivo in aged rats. Proc. Natl. Acad. Sci. USA. 79:3863-3866.

8. Clowes, A. W., M. M. Clowes, J. Fingerle, and M. A. Reidy. 1989. Kinetics of cellular proliferation after arterial injury. V. Role of acute distension in the induction of smooth muscle proliferation. Lab. Invest. 60:360-364.

9. Majesky, M. W., V. Lindner, D. R. Twardzik, S. M. Schwartz, and M. A. Reidy. 1991. Production of transforming growth factor $\beta_{1}$ during repair of arterial injury. J. Clin. Invest. 88:904-910.

10. MacLeod, D. C., B. H. Strauss, M. De Jong, J. Escaned, R.-J. van Suylen, P. W. Serruys, and P. J. de Feyter. 1994. Proliferation and extracellular matrix synthesis of smooth muscle cells cultured from human coronary atherosclerotic and restenotic lesions. J. Am. Coll. Cardiol. 23:59-65.

11. Timpl, R. 1993. Proteoglycans of basement membranes. Experientia (Basel). 49:417-428.

12. Bidanset, D. J., C. Guidry, L. C. Rosenberg, H. U. Choi, R. Timpl, and M. Hook. 1992. Binding of the proteoglycan decorin to collagen type VI. J. Biol. Chem. 267:5250-5256.

13. Paralkar, V. M., S. Vukicevic, and A. H. Reddi. 1991. Transforming growth factor- $\beta$ type 1 binds to collagen IV of basement membrane matrix implications for development. Dev. Biol. 143:303-308.

14. McCaffrey, T. A., D. J. Falcone, and B. Du. 1992. Transforming growth factor- $\beta$ is a heparin-binding protein: identification of putative heparin-binding regions and isolation of heparins with varying affinity for TGF- $\beta 1$. J. Cell Physiol. 152:430-440.

15. Falcone, D. J., T. A. McCaffrey, A. Haimovitz-Friedman, J. A. Vergilio, and A. C. Nicholson. 1993. Macrophage and foam cell release of matrix bound growth factors: role of plasminogen activation. J. Biol. Chem. 268:11951-11958.

16. Kelly, J. L., A. Sanchez, G. S. Brown, C. N. Chesterman, and M. J. Sleigh. 1993. Accumulation of PDGF B and cell-binding forms of PDGF A in the extracellular matrix. J. Cell Biol. 121:1153-1163.

17. Bashkin, P., S. Doctrow, M. Klagsbrun, C. M. Svahn, J. Folkman, and I. Vlodavsky. 1989. Basic fibroblast growth factor binds to subendothelial extracellular matrix and is released by heparitinase and heparin-like molecules. Biochemistry. 28:1737-1743.

18. Libby, P., D. Schwartz, E. Brogi, H. Tanaka, and S. K. Clinton. 1992. A cascade model for restenosis. A special case of atherosclerosis progression. Circulation. 86(Suppl. 3):III47-III52.

19. Wolf, E. C., M. H. Park, and J. E. Folk. 1990. Cleavage of spermidine as the first step in deoxyhypusine synthesis. The role of NAD. J. Biol. Chem. 265:4793-4799.

20. Abbruzzese, A., M. H. Park, and J. E. Folk. 1986. Deoxyhypusine hydroxylase from rat testis. J. Biol. Chem. 261:3085-3089.

21. Park, M. H., E. C. Wolff, and J. E. Folk. 1993. Hypusine: its posttranslational formation in eukaryotic initiation factor $5 \mathrm{~A}$ and its potential role in cellular regulation. BioFactors 4:95-104.

22. Park, M. H., S. I. Chung, H. L. Cooper, and J. E. Folk. 1984. The mammalian hypusine-containing protein, eukaryotic initiation factor 4D. J. Biol. Chem. 259:4563-4565.

23. Hanauske-Abel, H. M., M.-H. Park, A.-R. Hanauske, A. M. Popowicz, M. Lalande, and J. E. Folk. 1994. Inhibition of the G1-S transition of the cell cycle by inhibitors of deoxyhypusine hydroxylation. Biochim. Biophys. Acta. 1221:115-124.

24. Hanauske-Abel, H. M., and V. Günzler. 1982. A stereochemical concept 
for the catalytic mechanism of prolylhydroxylase. Applicability to classification and design of inhibitors. J. Theor. Biol. 94:421-455.

25. Hanauske-Abel, H. M. 1991. Prolyl-4-hydroxylase, a target enzyme for drug development. Design of suppressive agents and the in vitro effects of inhibitors and proinhibitors. J. Hepatol. 13(Suppl. 3):s8-s15.

26. Cunliffe, C. J., T. J. Franklin, N. J. Hales, and G. B. Hill. 1992. Novel inhibitors of prolyl hydroxylase. III. Inhibition by the substrate analogue $\mathrm{N}$-oxaloglycine and its derivatives. J. Med. Chem. 35:2652-2657.

27. Abbruzzese, A., H. M. Hanauske-Abel, M. H. Park, S. Henke, and J. E. Folk. 1991. The active site of deoxyhypusyl hydroxylase: use of catecholpeptides and their component chelator and peptide moieties as molecular probes. Biochim. Biophys. Acta. 1077:159-166.

28. Majamaa, K., H. M. Hanauske-Abel, V. Gunzler, and K. I. Kivirikko. 1984. The 2-oxoglutarate binding site of prolyl-4-hydroxylase. Identification of distinct subsites and evidence for 2-oxoglutarate decarboxylation in a ligand reaction at the enzyme-bound ferrous ion. Eur. J. Biochem. 138:239-245.

29. Majamaa, K., V. Gunzler, H. M. Hanauske-Abel, R. Myllyla, and K. I. Kivirikko. 1986. Partial identity of the 2-oxoglutarate and ascorbate binding sites of prolyl 4-hydroxylase. J. Biol. Chem. 261:7819-7823.

30. Ball, E. G., and T.-T. Chen. 1933. Studies on oxidation-reduction. XX. Epinephrine and related compounds. J. Biol. Chem. 102:691-719.

31. Park, M. H., H. L. Cooper, and J. E. Folk. 1982. The biosynthesis of protein-bound hypusine ( $\mathrm{N}^{\epsilon}$-(4-amino-2-hydroxybutyl)lysine). J. Biol. Chem. 257:7217-7222

32. Tschank, G., M. Raghunath, V. Gunzler, and H. M. Hanauske-Abel. 1987. Pyridinecarboxylates, the first mechanism-derived inhibitors for prolyl 4-hydroxylase, selectively suppress cellular hydroxyprolyl biosynthesis. Biochem. J. 248:625-633.

33. Dunphy, M. J., M. V. Bhide, and D. J. Smith. 1987. Determination of hydroxyproline in tissue collagen hydrolysate by derivatization and isocratic reversed-phase high-performance liquid chromatography. J. Chromatogr. 420:394397.

34. Dawson, C. D., S. Jewell, and W. J. Driskell. 1988. Liquid-chromatographic determination of total hydroxyproline in urine. Clin. Chem. 34:15721574.

35. Vuori, K., T. Pihlajaniemi, M. Marttila, and K. I. Kivirikko. 1992. Characterization of the human prolyl 4-hydroxylase tetramer and its multifunctional protein disulfide-isomerase subunit synthesized in a baculovirus expression system. Proc. Natl. Acad. Sci. USA. 89:7467-7470.

36. Hojima, Y., M. van der Rest, and D. J. Prockop. 1985. Type I procollagen carboxyl-terminal proteinase from chick embryo tendons. J. Biol. Chem. 260:15996-16003.

37. Histologic Staining Methods. 1968. Armed Forces Institute of Pathology, Washington, DC. 94 pp.

38. Gown, A. M. 1992. Cell type and cell state specific antibodies in the analysis of early lesions of human atherosclerosis. Am. J. Hypertens. 5(Suppl):114S-117S

39. Bjorkerud, S. 1991. Effects of transforming growth factor- $\beta 1$ on human arterial smooth muscle cells in vitro. Arteriosclerosis. 11:892-902.

40. Ronnov-Jessen, L., and O. W. Petersen. 1993. Induction of $\alpha$-smooth muscle actin by transforming growth factor- $\beta 1$ in quiescent human breast gland fibroblasts. Implications for myofibroblast generation in breast neoplasia. $L a b$. Invest. 68:696-707.

41. Günzler, V., K. Majamaa, H. M. Hanauske-Abel, and K. I. Kivirikko. 1986. Catalytically active ferrous ions are not released from prolyl 4-hydroxylase under turnover conditions. Biochim. Biophys. Acta. 873:38-44.

42. Okac, A., and Z. Kolarik. 1959. Potentiometrische Untersuchung von Komplexsalzen der Kojisäure in wässringen Lösungen. Collect. Czech. Chem. Commun. 24:266-272.

43. Stünzi, H., D. D. Perrin, T. Teitei, and R. L. Harris. 1979. Stability constants of some metal complexes formed by mimosine and related compounds.

Aust. J. Chem. 32:21-30.

44. Mayne, R. 1987. Vascular connective tissue: normal biology and derangement in human diseases. In Connective Tissue Disease. Molecular Pathology of the Extracellular Matrix. J. Uitto and A. Perejda, editors. Marcel Dekker, Inc., New York. 163-183.

45. Bonnet, J., P. E. Garderes, M. Aumailley, C. Coreau, G. Gouverneur, D. Benchimol, R. Crockett, J. Larrue, and H. Bricaud. 1988. Serum type III procollagen peptide levels in coronary artery disease (a marker of atherosclerosis). Eur. J. Clin. Invest. 18:18-21.

46. Prockop, D. J., R. A. Berg, K. I. Kivirikko, and J. Uitto. 1976. Intracellular steps in the biosynthesis of collagen. In Biochemistry of Collagen. G. N. Ramachandran and A. H. Reddi, editors. Plenum Publishing Corp., New York. 163273.

47. Kivirikko, K. I., R. Myllyla, and T. Pihlajaniemi. 1989. Protein hydroxylation: prolyl 4-hydroxylase, an enzyme with four cosubstrates and a multifunctional subunit. FASEB (Fed. Am. Soc. Exp. Biol.) J. 3:1609-1617.

48. Chessler, S. D., and P. H. Byers. 1992. Defective folding and stable association with protein disulfide isomerase/prolyl hydroxylase of type I procollagen with a deletion in the proa2(I) chain that preserves the Gly-X-Y repeat pattern. J. Biol. Chem. 267:7751-7757.

49. Majamaa, K., T. M. Turpeenniemi-Hujanen, P. Latipaa, V. Gunzler, H. M. Hanauske-Abel, I. E. Hassinen, and K. I. Kivirikko. 1985. Differences between collagen hydroxylases and 2-oxoglutarate dehydrogenase in their inhibition by structural analogues of 2-oxoglutarate. Biochem. J. 229:127-133.

50. Takahara, S., and H. Takahashi. 1972. An amine inducing alopecia in mice. J. Biochem. 72:195-197.

51. Porreca, E., S. Ucchino, C. DiFebbo, N. DiBartolomeo, D. Angelucci, A. M. Napolitano, A. Mezzetti, and F. Cuccurullo. 1994. Antiproliferative effect of desferrioxamine on vascular smooth muscle cells in vitro and in vivo. Arterioscler. Thromb. 14:299-304.

52. Reis, P. J., D. A. Tunks, and M. P. Hegarty. 1975. Fate of mimosine administered orally to sheep and its effectiveness as a defleecing agent. Aust. J. Biol. Sci. 28:495-501.

53. Lambert, C. R., J. E. Leone, and S. M. Rowland. 1993. Local drug delivery catheters: functional comparison of porous and microporous designs. Coron. Artery Dis. 4:469-475.

54. Rogers, C., M. J. Karnovsky, and E. R. Edelman. 1993. Inhibition of experimental neointimal hyperplasia and thrombosis depends on the type of vascular injury and the site of drug administration. Circulation. 88:1215-1221.

55. Schwartz, S. M., C. H. Haudenschild, and E. M. Eddy. 1978. Endothelial regeneration. I. Quantitative analysis of initial stages of endothelial regeneration in rat aortic intima. Lab. Invest. 38:568-580. 